鐵と鋼 第十五年 第三號

昭和四年三月廿五日發行

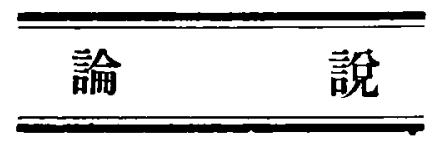

\title{
鉻鐄蠦に於ける珪素の還元に對する實驗
}

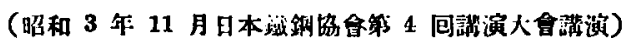

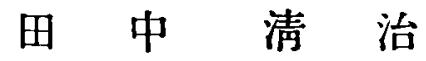

\section{LABORATORY EXPERIMENTS ON THE REDUCTION OF SILICON IN THE BL.AST FURNACE}

\author{
by Seiji. Tanaka. Kugakushi
}

The author carried out experiments on the reduction of Silicon out of silica in iron ores. The ore, cruslied into Small pieces, was reduced with Carbon monoxide and the reduced iron was carburised at $\mathrm{h}$ gh temperatures upto $1350^{\circ} \mathrm{C}$. The pig iron, thus produced was analysed. The results of the experiments were as follows

1. The Silicon rontent of the pig iron produced from the self-fluxing ore was very murh small compaired with that of the pig iron from the quartziferous iron ore.

2. The pig iron from the self-fluxing ore had much finergrapbide structure than that of the quartziferous ore.

3. The reduction of silicon scarcely occured in Carbon monoxide gas, but was accelerated as the gas was diluted with Nitrogen. Too much diluted Carbon monoxide gas, however, delayed the carburization of the reduced jron and the long time was required for the production of $p: g$ iron and redrction of silicon.

4. The author carried out also the experiments on the reduction of silicon with electric iron as Hans Meyer's (Mitt. Kaiser-Wilh. Inst. Bd 9 Ueber die Reduktion von MnO, $\mathrm{SiO}_{2}$ und $\mathrm{P}_{2} \mathrm{O}_{5}$ im Hoch ofen)

The electric iron was covered with the mixture of eilica and charcoal powder and heated in the electric furnace in the atmosphere of Nitrogen and in the mixture of $62,0 \mathrm{Nit}$ rogen and 33\% Carbon monoxide gases, during 1 hour at the temperature of $1,260^{\circ} \mathrm{C}$

The Silicon content of the iron, which heated in Nitrogen was $19 \%$ and the other con* tained only $0.46 \%$ Silicon Dr. Wäst has quoted in his puper "Eine neue Theorie des Hochofen Verfahren". the results of the Hans Mejer's for confermation of his theory. The Meyer's experiments. however, has feen carried out in Nitrogen and Hydrogen, accordingly it is wrong to anply the resuits to the blast furnace reaction. 


\section{內，客目决}

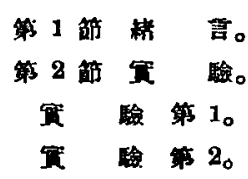

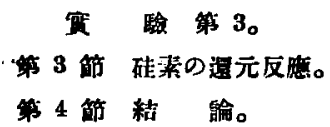

第 1 節 緒

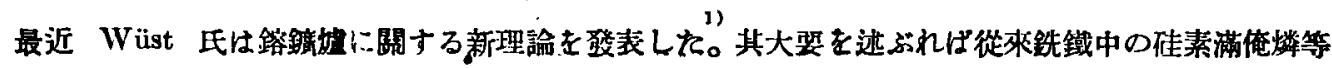

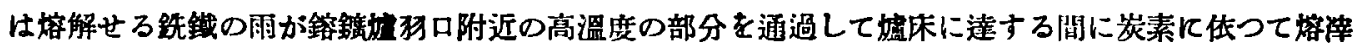

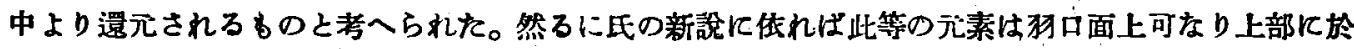

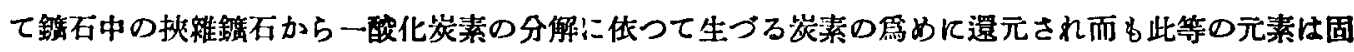
體の鐵中にヒメンテーションに依つて罗收される。而して狗口面附近の高溫部に於て楁解し炣口直前 の酸化园內滴下寸る間に鐵は酸化され同時に此等の元素も又酸化される，爐床中の鑑滓は酸化鐵に

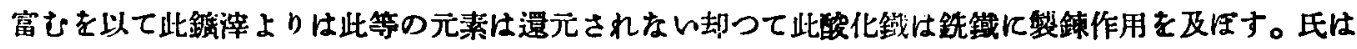

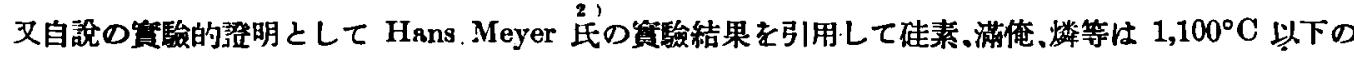

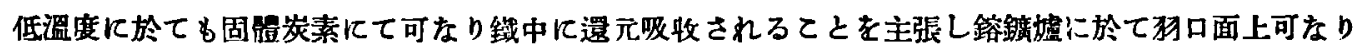
上部に於て巳に銑鐵恃出來あがり犸口附近に於て單に揢解するのみであると云つて居る。

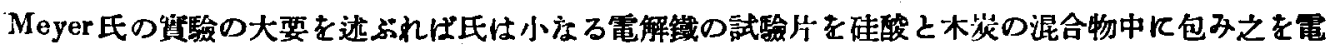
氣㠊中にてて水素瓦斯。室素瓦斯及び一酸化炭素瓦斯等の氣流中に加熱し佳素の還元を筫驗した其結果

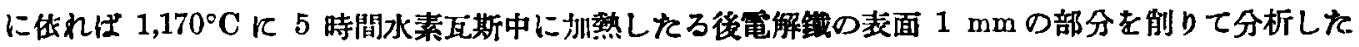
るに硅素132\%であつた。次に試驗片と混合物との接解面を大にする目的にて細い針金を使用し炭素

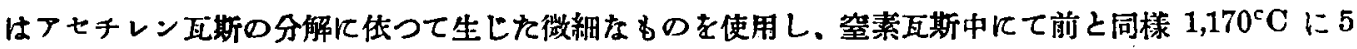
時䦓加熱した。硅素は 255\% で前試驗の 2 倍も還元した。向一酸化炭素瓦斯中にて賽驗したが此結 果は前試驗結果に比し比較になら程還元しなかつた。

氏は此等の事賽に對して單に接渴面の大小に就てのみ考へ瓦斯の影䇾に就ては何等考へて居らな n。

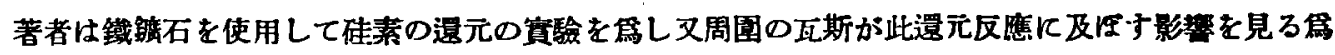

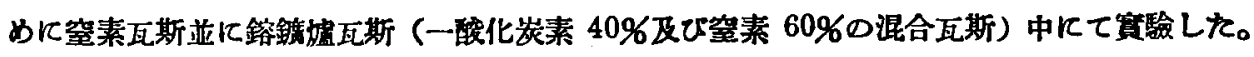

\section{第 2 笛寞楼}

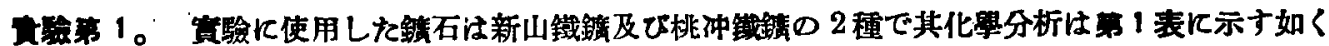
でする。

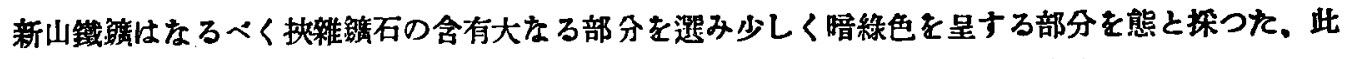
銭石は分析表に示す如く佳酸分は甚だ多量ですり且石灰。苦土等は多量であつて所謂 Self-fluxing 


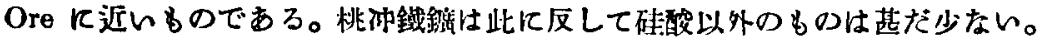

\begin{tabular}{|c|c|c|c|c|c|c|}
\hline & $\begin{array}{l} \\
(\%)\end{array}$ & 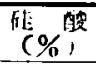 & $(\%)$ & $\begin{array}{l}\text { Ti } \\
(\%)\end{array}$ & $\begin{array}{l}\text { 苦 } \\
(\%)\end{array}$ & 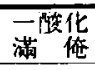 \\
\hline 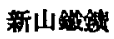 & $43 \cdot 5$ & $20 \cdot 2$ & 1.35 & $8 \cdot 50$ & $5 \cdot 21$ & 0005 \\
\hline 桃冲较鐵 & $63 \cdot 0$ & 671 & 0.86 & 0.29 & $0 \cdot 31$ & $0 \cdot 200$ \\
\hline
\end{tabular}

以上 2 つ代表的鐵錉を取り先づ 2 乃至 $4 \mathrm{~mm}$ 大江碎导一酸化炭素政斯に て光分還元して所謂還元鐵を作る。此 を約 $4 \mathrm{gr}$ を术炭䌘の小なるポートに取 り之を約 $2 \mathrm{~mm}$ 大の木炭粹にて嘚し雪氣嘘中にて一酸化炭素を通しつ〉高溫度に上け銑鐵を作り之を

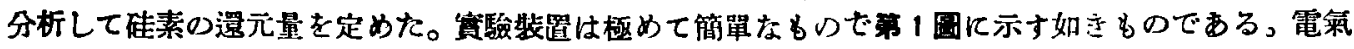

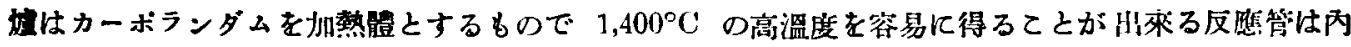
徑 $20 \mathrm{~mm}$ 長さ $530 \mathrm{~mm}$ の のである。四斯は岑酸し斯、酸素及び水分等を除去して 1 時間䄪 2 立の 割合にて反然管中に通する。

䆩驗の促件及び其結果は第 2 表に示す。

\begin{tabular}{|c|c|c|c|}
\hline \multirow{2}{*}{ 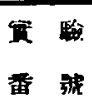 } & \multicolumn{2}{|c|}{ 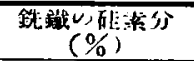 } & \multirow{2}{*}{ 芧 監 の 狀 件 } \\
\hline & 新 山 & 桃冲 & \\
\hline No. 1 & $\begin{array}{l}0.04 \\
\text { 乃至 } \\
0.06\end{array}$ & $\begin{array}{c}0 \cdot 15 \\
\text { 乃至 } \\
0 \cdot 21\end{array}$ & 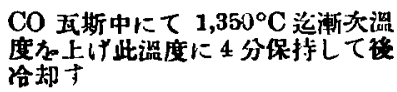 \\
\hline No. 2 & 同上 & 同上 & 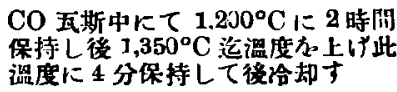 \\
\hline No. 3 & & 0.27 & 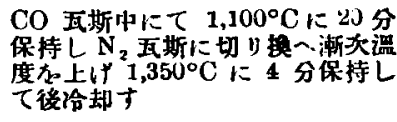 \\
\hline No. 4 & & $\begin{array}{l}0.57 \\
0.41\end{array}$ & 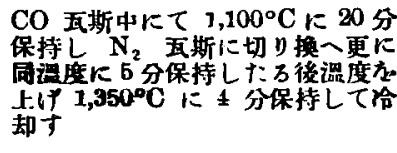 \\
\hline No. 5 & 0.21 & $\begin{array}{l}1 \cdot 18 \\
108\end{array}$ & 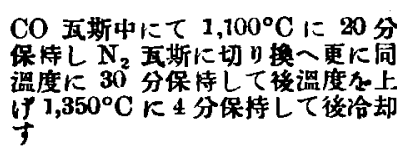 \\
\hline No. 6 & 0.50 & $\longrightarrow$ & 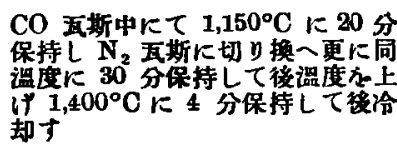 \\
\hline No. 7 & & 0.37 & 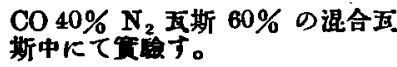 \\
\hline
\end{tabular}

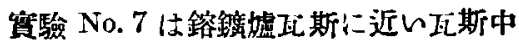
に巵された賽驗であるが此場合は炭素の 吸收おこく中ふ鉄鐵が出來なかつた。長 時間を要して漸く鉄鐵を得てが烣素分は $3.7 \%$ 佳素分は $0.37 \%$ であつた。第 2 圖は上表の實驗に於ける加熱溫度及其速 度を大䯏圆示したものである、横軸には 時間。縱軸には溫度を取り。蟹線驻一酸 化炭素瓦斯、點線部は窒素正斯中の扣熱 を示す。

以上の賽䮦絬果から次の結論を得た。

（1）鉎鐵中の硅素は比較的低溫度に て一酸化炭素及其含有瓦斯中にて鏣石中 の㣣雜鑑石より還元される。

（2）一酸化炭素瓦斯中では $1,400^{\circ} \mathrm{C}$ 迄の筫簽に於ては硅素は還元し難い。

（3）一酸化炭素中に窒素を次第に增 加する時は漸次硅素の還元が盛んになる。此事賽は此反應式より直に了解出來ることである。 $\mathrm{SiO}_{2}+2 \mathrm{C}=\mathrm{Si}+2 \mathrm{CO}$

䇪素瓦斯を加へてー酸化炭素瓦斯の分涯を減少する程硅素の還元は容易になる等である此事に就ては 
s

1

[固

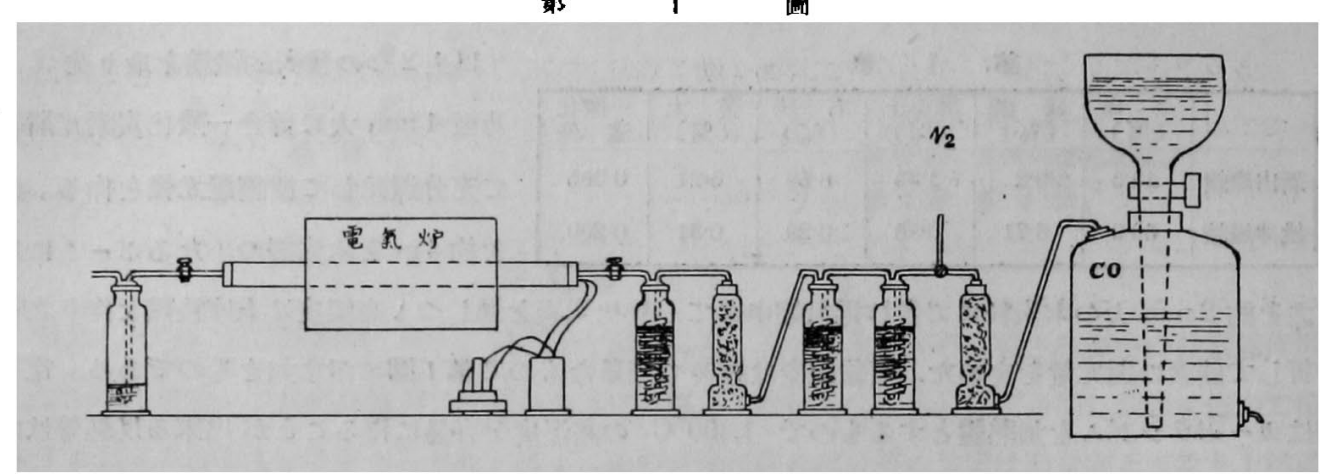

第 2 圆

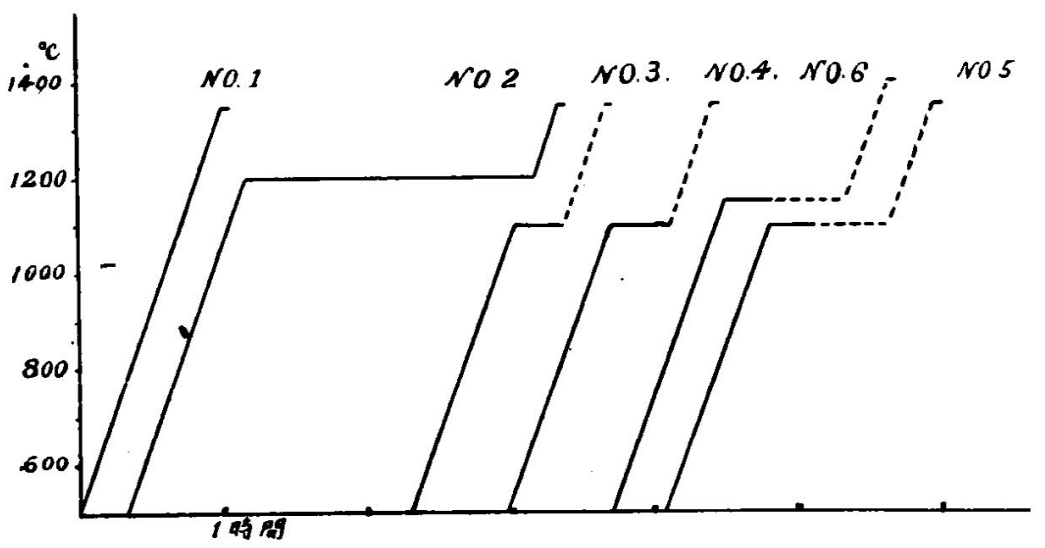

㷋節に就て記载する。

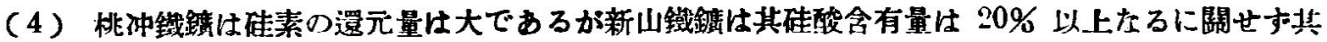

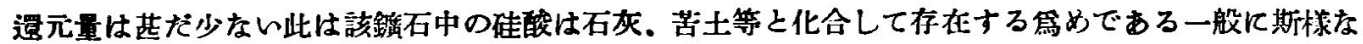

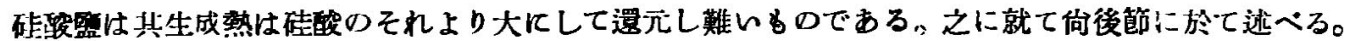

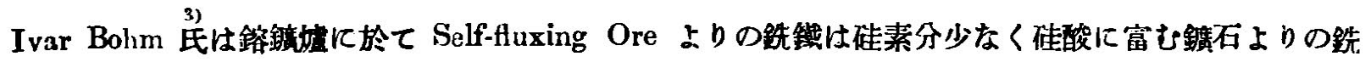

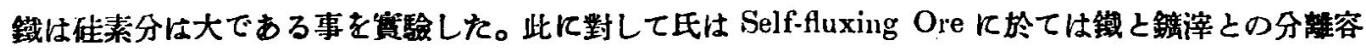

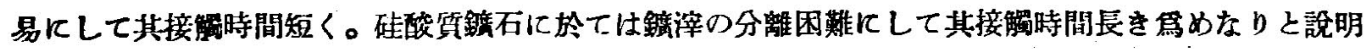
して居る。

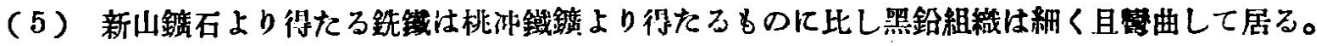
（竄真圆寥照） 


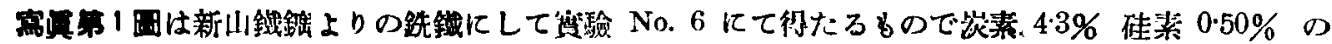

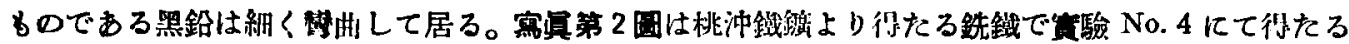

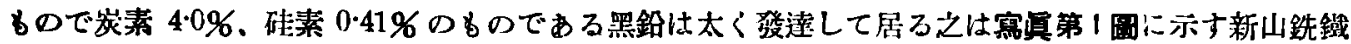

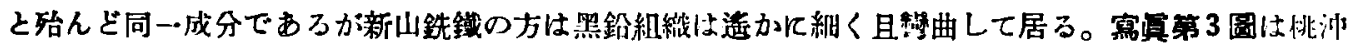

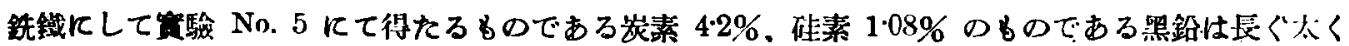

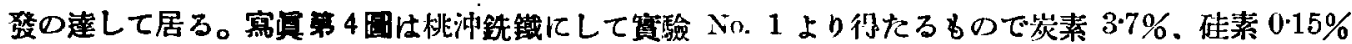

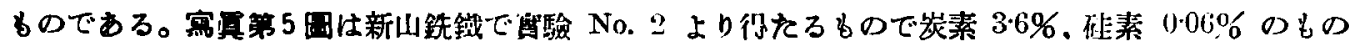

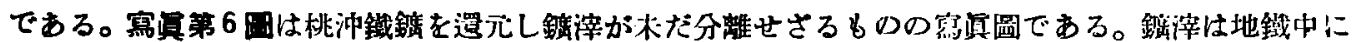
微編に介在して居るを示す。

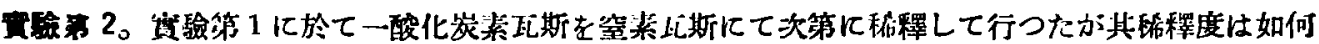

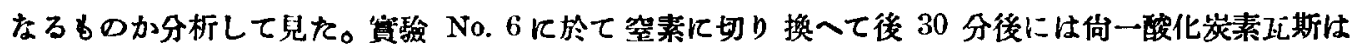

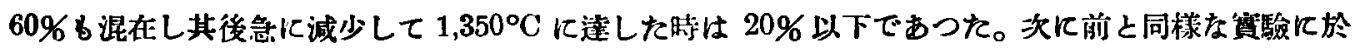
て一酸化炭素に斯を $1,100^{\circ} \mathrm{C} に 20$ 分通した後全く空素扎斯のみを通して見た。處が鉄鐵は仙來す 传つて之を更に一酸化炭素瓦斯中に加熱して鉎鐵を作り分析したるに硅素は殆んど還元しなかつた。

此實驗絬果より谴元鐵と木炭塊との表面接触にては炭素は容易に謾收されないてとが解る。從つて 又硅素も還元されない。此炭素は一酸化炭素より來たてとが明かでする。此は一般に認められた事實で

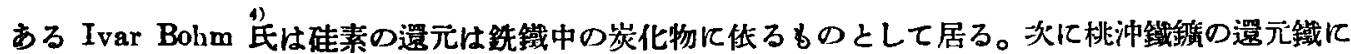

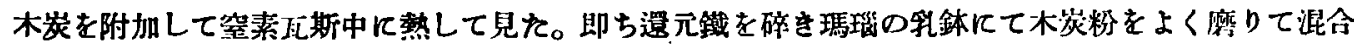

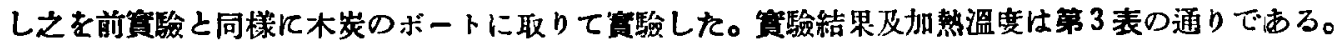

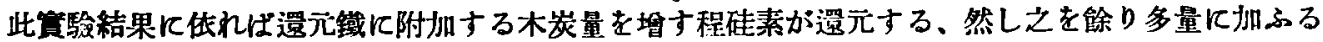

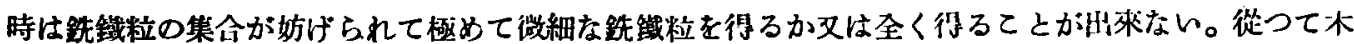
炭は制限される。察真第 7 圆は炭素 $5 \%$ を附加して $1,350^{\circ} \mathrm{C}$ 迄加熱して得た鉄鐵量である。全く白铁

第 3 表

\begin{tabular}{|c|c|c|c|c|}
\hline \multicolumn{3}{|c|}{ 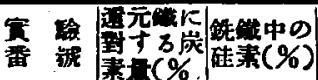 } & \multicolumn{2}{|c|}{ 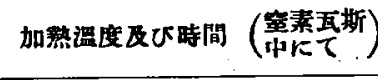 } \\
\hline No. 1 & 30 & 0.28 & $\begin{array}{l}1,200^{\circ} \mathrm{C}-20 \text { 分 } \\
1,350^{\circ} \mathrm{C}-10 \text { 分 }\end{array}$ & $\begin{array}{l}1,300^{\circ} \mathrm{C}-20 \text { 分 } \\
1,100^{\circ} \mathrm{C}-5 \text { 分 }\end{array}$ \\
\hline No. 2 & 4.6 & 1.73 & 同 & 上 \\
\hline No. 3 & $7 \cdot 0$ & $2 \cdot 40$ & 同 & 上 \\
\hline No. 4 & $9 \cdot 0$ & 1.96 & $\begin{array}{l}1,200^{\circ} \mathrm{C}-20 \text { 分 } \\
1,350^{\circ} \mathrm{C}-5 \text { 分 }\end{array}$ & $1,300^{\circ} \mathrm{C}-10$ 分 \\
\hline No. 5 & $7 \cdot 0$ & 1.40 & $1,250^{\circ} \mathrm{C}-90$ 分 & \\
\hline
\end{tabular}

鐵にして硅素 0.75\% である。

莫颐第 3。前實驗では炭素を過剩に加 ふることが出來ない故に本䨘驗に於ては 電解鐵を使用し之を過剩の木炭粉枺と硅 酸又は鉻鋂墟鐵涬の混合物にて包み、之 を前进の電氣爐中にて窒素卭斯及び窯素 $62 \%$ 一酸化炭素 $38 \%$ の混合瓦斯中にて 加熱し硅素の買元を試驗した。電解鐵は

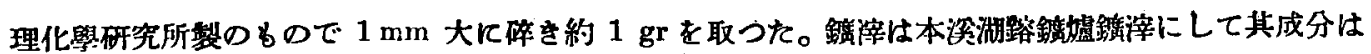
次の如し。 
留驗の狀能及結果は第 4 表に示す如くである。

表中笔素 62\% 一酸化炭素 38\% の泿合扎斯は J Jonnings に

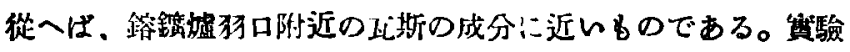
No. 1 及び No. 2 とを比較すれば還元した佳素量は附加した硅 酸の是に比例するととが解る。即ち接触面秥に比例するととが

\begin{tabular}{|c|c|c|c|c|}
\hline & \multicolumn{4}{|c|}{ 本湖输㴖の成分 (\%) } \\
\hline 珄 & 毁 & $27 \cdot 25$ & 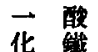 & 0.96 \\
\hline 禁 & 士 & 16.44 & 硫，絾 & $2 \cdot 50$ \\
\hline 石 & 质 & $47 \cdot 36$ & 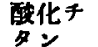 & $0 \cdot 10$ \\
\hline 苦 & \pm & $5 \cdot 15$ & & \\
\hline
\end{tabular}

解る、筫驗 No. 1 と No. 3 とを比較すれ代 No. 3 の方は約 4 倍以上も硅素が還元して居る。即ち窒素瓦

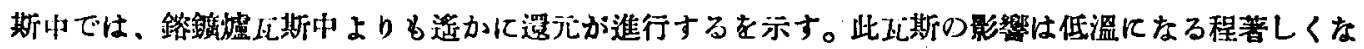

\begin{tabular}{|c|c|c|c|c|c|c|}
\hline 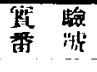 & 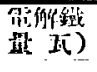 & 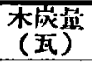 & 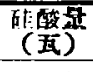 & 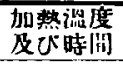 & 五 & 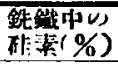 \\
\hline No. 1 & $0-60$ & $0 \cdot 20$ & 0.06 & $\begin{array}{l}1260^{\circ} \mathrm{C} \\
\text { に } 1 \text { 時間 }\end{array}$ & 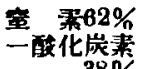 & 0.46 \\
\hline No. 2 & 100 & 0.20 & 0.02 & $"$ & " & $0 \cdot 16$ \\
\hline No. 3 & 0.60 & 0.20 & 0.06 & " & 垐 & 1.90 \\
\hline No. 4 & 0.60 & 0.20 & $0 \cdot 20$ & 4 & $"$ & $0 \cdot 12$ \\
\hline
\end{tabular}
らべをに依り前达の Meyer 氏 の筫驗溫度 $1,170^{\circ} \mathrm{C}$ の如先低溫 度に於ては一層此影暨忙甚だし レものと想像される。從つて。 Moyer 氏の實驗の結果を以て 鉻鋌㠊队の反應を說明する事が

比來ない。

此點に於てWüst 氏の宩は誤つて居ると言はねばならね。鉻鍍嘘內に於ては佳素は同氏の云ふ如 く $1,100^{\circ} \mathrm{C}$ の低溫に於てそら容易に還元するものではないことが解る。實驗 No. 4 に於て鏣涬の混合

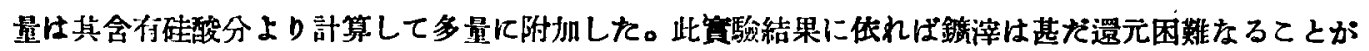

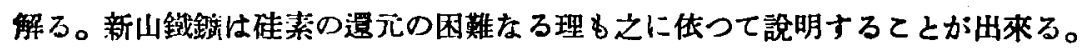

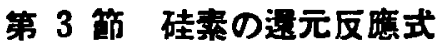

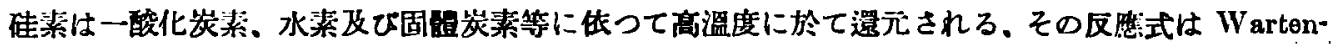
berg 氏に偖れば次に示す如くである。

$$
\begin{aligned}
& \mathrm{Si}_{\text {(yas) }}+2 \mathrm{CO}_{2}=\mathrm{SiO}_{2}+2 \mathrm{CO}+59,000+44,000+2 T \\
& \mathrm{Si}_{\text {(Fan) }}+2 \mathrm{H}_{2} \mathrm{O}=\mathrm{SiO}_{2}+2 \mathrm{H}_{2}+79,000+44,000+2 T \\
& \mathrm{Si}_{\text {(Fas) }}+2 \mathrm{CO}=\mathrm{SiO}_{2}+2 \mathrm{C}+143,000+44,000+2 T
\end{aligned}
$$

以上の各式は硅素分子は 1 原子よりなる場合の反應式である。ての外飞 2 原子 3 原子又それ以上の

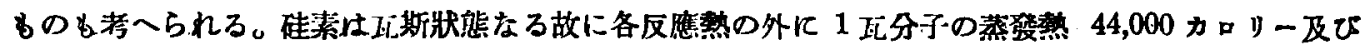
其蒸發の際の椸腿の仕事 $R T .(=2 T)$ を附加するを要す。

以上の各反應式さり Wartenberg 氏がネルンスト氏の近似式を使用して各温度に於ける硅素正斯の 分压を計算した。

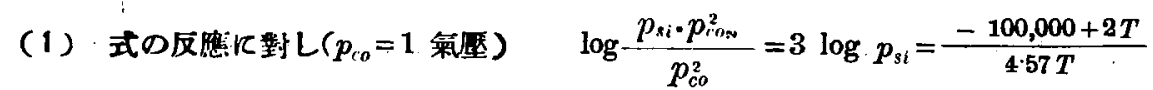
$+1 \cdot 75 \log T+2 \cdot 4$ 


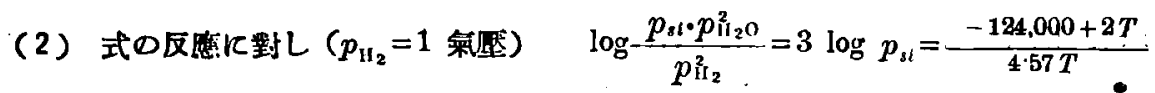
$+1 \cdot 75 \log T+7 \cdot 0$

(3) 式の反應几對し $\log p_{s i} p_{c 0_{2}}=3 \log p_{s i}=\frac{-187,000+2 T}{4 \cdot 57 T}+3 \times 1 \cdot 75 \log T+10 \cdots$ (6)

以上の各式の最後の數字の項は各瓦斯の化等恒数の代数的和である。(6) 式は硅素の炭素几依る還

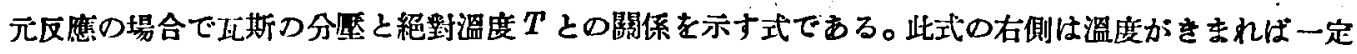
の數值である。即ち佳素の分厘と一酸化炭素の分厓の二乘の樍は恒溫にては一定である。從つて此反

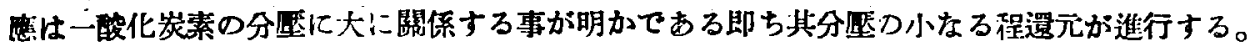

上二の各式より計算せる硅素の分癷は第 5 表及ひ第 6 表に示す゚

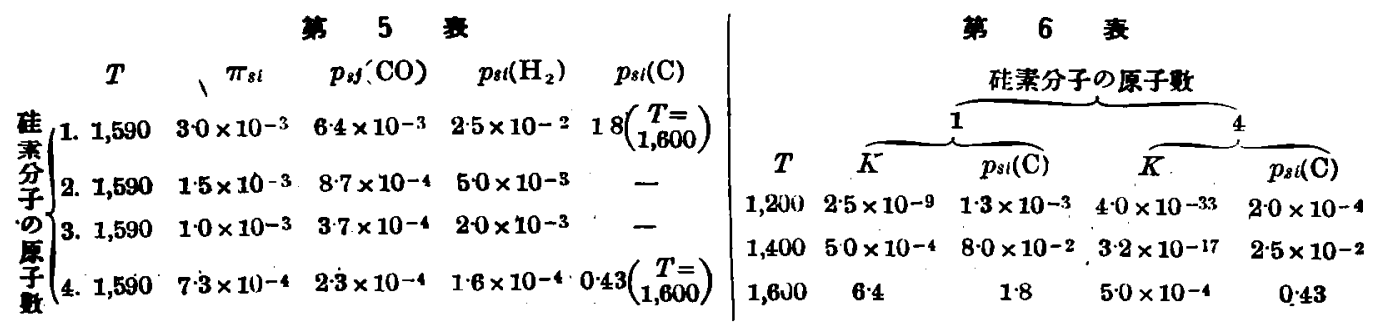

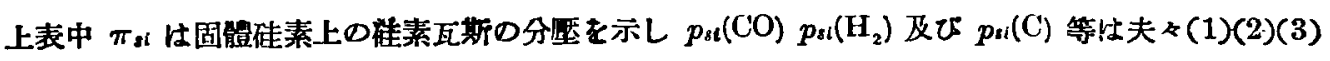
式の反應に於ける佳素瓦斯の分压を示す。 $K$ は本衡恒数でする、第 5 表上り明かなる如く炭素は最

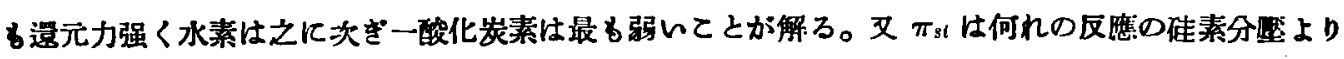

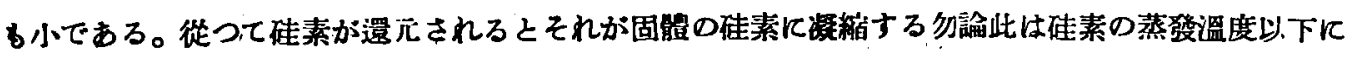
於てのてとでする此蒸墢盢度は明かならされど $1,450^{\circ} \mathrm{C}$ 附近の如し。

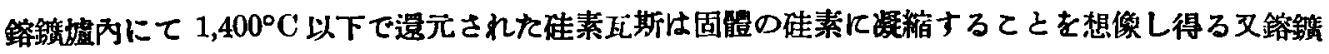
坡內の瓦斯の速度恃可なり速いものであるが此の速度も此還元反應を促進することを想像し得る。

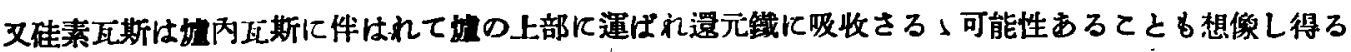

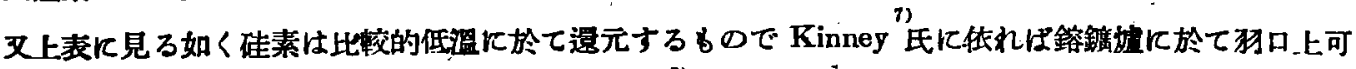

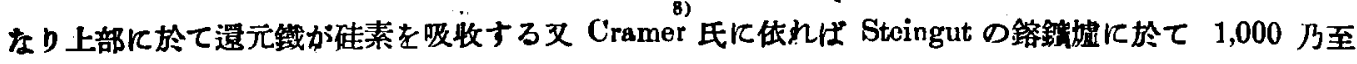
$1,300^{\complement} \mathrm{C}$ の低溫部に硅酸の沈積を認めた。

\section{第 4 䈱 結詥}

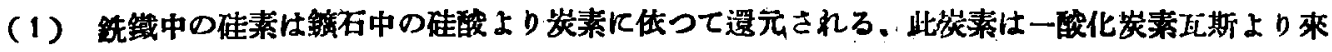

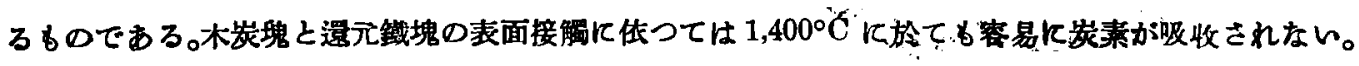

(2) 硅素江瓦斯體にてセメンテーションに低り固體鐵中に入る。

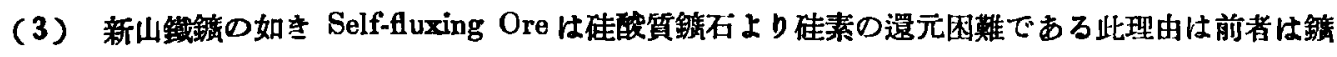

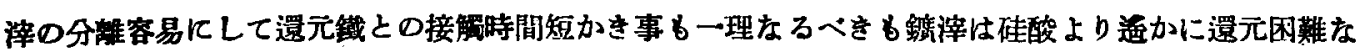
ろ事が主なる理由と考へられる。 


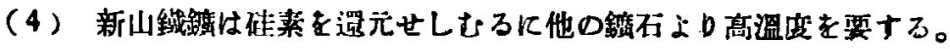

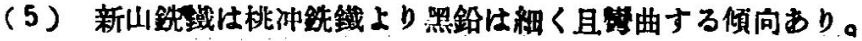

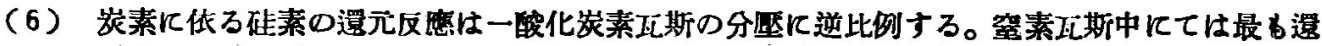

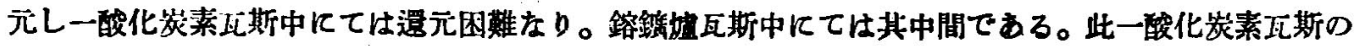
影響は低溫になる程著しくなる、從つて Meyer 氏の鿓驗に於て $1,170^{\circ} \mathrm{C}$ の低溫几て窒素及び水素瓦

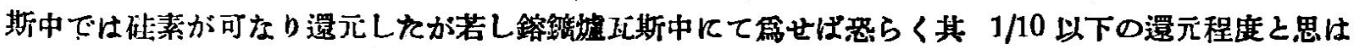

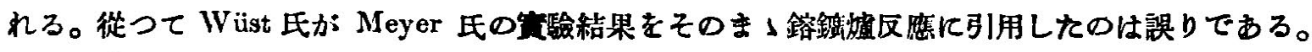

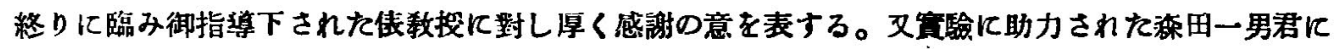
對し溥く感謝する。

\section{明和4 年2月28 日}

1) St. u. E 48 (1928) S 505/6; St. u. E. 13 sep. 1928; Iron and Steel Inst. 1927.

2) Mitt. Kais. Wilh. Inst. Bd. 9.

3) Iron and Steel Inst. 1927 p 83/4.

4) 同上
5) Marz. 1928 Archiv. Eisen hutten wesen.

6) Zeit. Anorg. Chem.

7) U. S. B. M. Tech. Paper No. 397. 1926. !

8) Zeit Angew. Chem. 1892.

(娄口)

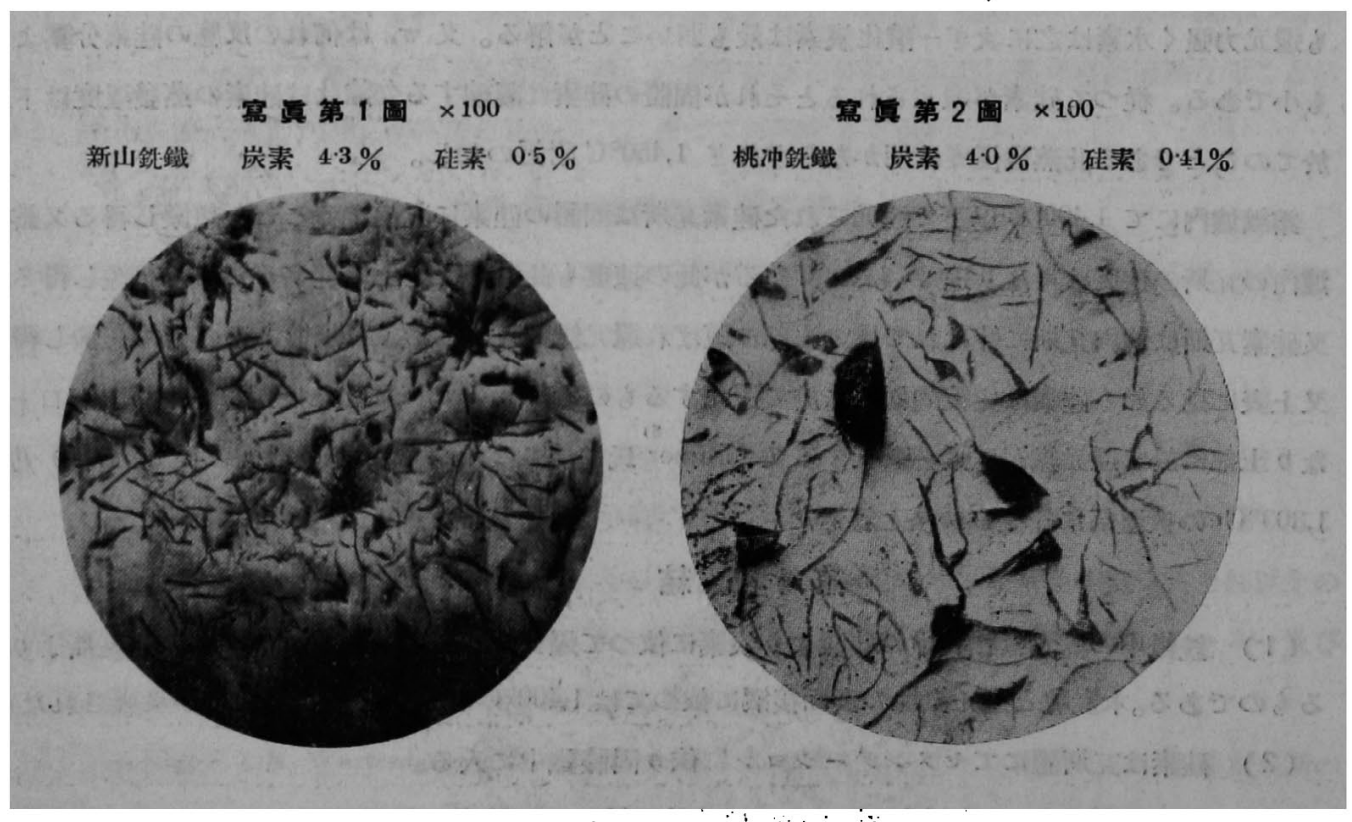




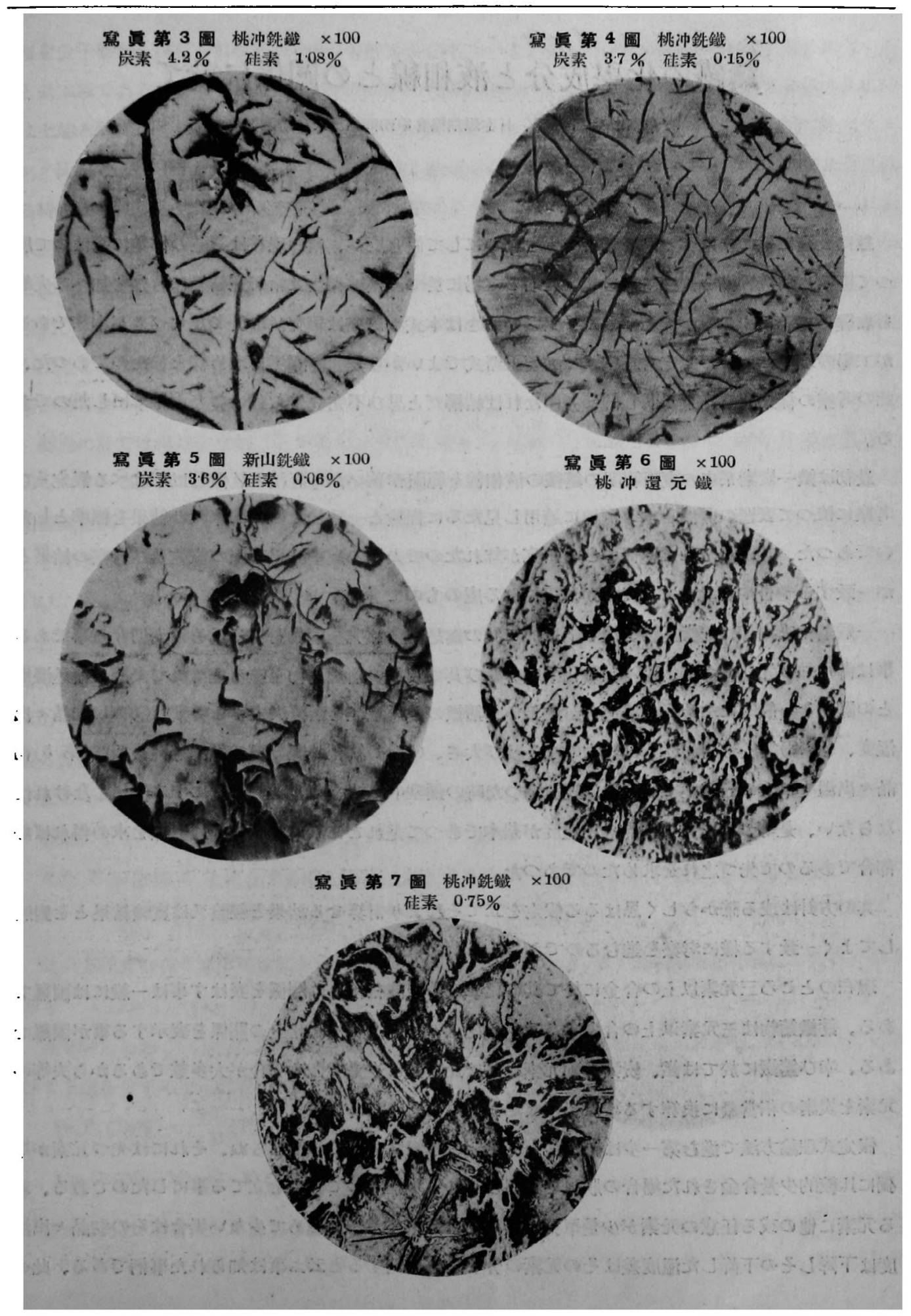

